\title{
FAMILY VALUES: THE RECOGNITION OF SAME-SEX RELATIONSHIPS IN INTERNATIONAL LAW
}

\author{
LOVEDAY HODSON*
}

\begin{abstract}
There are currently no international human rights treaties in force that explicitly provide for the recognition and protection of same-sex relationships. The 'family' that is safeguarded under human rights treaties has been consistently defined in a heterosexual way. The consequence of non-recognition of same-sex relationships is a considerable degree of suffering and discrimination. This article questions whether it is justifiable for the international law of human rights to deny its protection to those people in same-sex relationships. It points in particular to recent developments that have taken place in many countries towards offering these relationships legal recognition. This article concludes that, given its commitment to equality and tolerance, international human rights law's failure to recognise same-sex relationships is increasingly untenable.
\end{abstract}

\section{INTRODUCTION}

There are currently in force a vast (and ever-increasing) number of international and regional human rights treaties that aim to ensure that all 'are born free and equal in dignity and rights';' many of which offer special protection to 'the family' unit. In several countries in recent years there have been remarkable legal and social developments concerning the rights of same-sex couples, ${ }^{2}$ along with an increasing global awareness of the discrimination that is suffered by gay people. ${ }^{3}$ It therefore seems surprising that not one of these human rights treaties expressly provides for the recognition and protection of gay relationships, and that these relationships have yet to be accepted as being included within the definition of 'the

\footnotetext{
* Ph.D. Student, University of Warwick, Coventry, the United Kingdom.

1 Article 1, Universal Declaration of Human Rights 1948.

2 In this article I use the terms 'same-sex relationships' and 'gay relationships' interchangeably.

3 For a study of global discrimination against homosexuals, see Amnesty International, Breaking the Silence: Human Rights Violations Based on Sexual Orientation, Amnesty International, London, 1995 and Amnesty International, Crimes of hate, conspiracy of silence: Torture and ill-treatment based on sexual identity, Amnesty International, London, 2001. See also the web-site of the International Gay and Lesbian Human Rights Commission at www.iglhrc.org.
} 
family' that these treaties do protect. In the enforcement of negative gay rights, that is in the prevention of interference by States in gay (usually males') sexual lives by means of criminal law, international human rights treaties have proved a valuable asset. However, it is the want of legal recognition of gay relationships, and their consequential lack of positive rights and legal protection, that is currently the greatest discrimination against gay people in many countries. Recognising the equal value of gay relationships and respecting the right to form and maintain these bonds is something that the international community has hitherto been unwilling to address.

This article asserts two propositions. Firstly, that 'the family' is a social and legal construct, the aim of which is to privilege certain relationships within society. This is true both at the national and the international level. Deciding which relationships to privilege is therefore intrinsically linked to the social and cultural norms of any society, making it an enormously complex and sensitive issue for human rights tribunals to grapple with. Secondly, 'the family' international human rights law has so far recognised and protected has been broadly defined, but only within a heterosexual context. It has so far excluded same-sex relationships. It is therefore the responsibility of the international community to question whether there are any satisfactory reasons for this exclusion. This article also asks whether, in light of the increasing global acceptance of homosexuality in many countries and the significant steps made at the domestic level towards placing same-sex relationships within a legal framework, this position remains tenable. Human rights tribunals must avoid ignoring discrimination that is based upon prejudice alone, otherwise they merely perpetuate the current power structures; they must also avoid remaining unaffected of global developments or else they risk appearing irrelevant and out-of-touch.

\section{HOW HAS 'THE FAMILY' BEEN DEFINED IN INTERNATIONAL HUMAN RIGHTS LAW?}

Since the 1948 Universal Declaration of Human Rights was adopted by the General Assembly of the United Nations the international community has expressed its concern for the protection of 'the family'. ${ }^{4}$ Several major international and regional human rights treaties now offer protection to this unit. ${ }^{5}$ However most of the monitoring bodies created by these treaties have provided little analysis as to what 'the family' they are offering protection to

Article 16(3).

For example see Article 23 of the UN's International Covenant on Civil and Political Rights; Article 8 of the European Convention on Human Rights; Article 18 or the African Charter on Human and Peoples' Rights; Article 11 of the American Convention on Human Rights, 1969. 
is. ${ }^{6}$ This is, perhaps, unsurprising given the sensitivity of this issue and the great number and diversity of States that have ratified some of the treaties in question. ${ }^{7}$ Definitions of 'the family' vary enormously and are linked to the traditions and cultural mores and norms of a society. To argue for the acceptance of gay relationships can be interpreted as a serious challenge to fabric of society, whose stability depends upon the dominance of heterosexual norms. As Howard-Hassmann argues:

'Their very desire to join society by forming their own recognized family units is seen as an attack on the family. ${ }^{8}$

To define what 'the family' is is therefore not a task that many human rights tribunals have shown willing to tackle, preferring rather to leave the question to States themselves.

The unfortunate consequence of this is that the treaty monitoring bodies are remaining outside of discussions about whether gay relationships can be or ought to be defined as familial and therefore offered their protection. In most cases this stems from shared heterosexist assumptions about the language of the treaties meaning that the question of recognising gay families is never even raised. Where this issue has been raised, for example in applications to the monitoring bodies of the European Convention on Human Rights, there is marked reluctance on the tribunals' part to interfere with domestic laws and practice in respect of recognition of gay relationships. It seems therefore that human rights bodies have little to say about this question, leaving it a matter for States to contend with alone. Whether explicitly or implicitly human rights bodies have consequently colluded with the discriminatory treatment of people in gay relationships. Without recognising that there is a debate to be had and without fully entering in to the discussion the tribunals have been unable to say whether this discrimination is an unjustifiable violation of human rights. This is an abdication of responsibility.

6 This is less true of the European Convention on Human Rights monitoring bodies, which is unsurprising given the comparative homogeneity of the Member States, at least up until recent years.

Brazil's recent attempt to introduce a resolution on human rights and sexual orientation at the UN Commission on Human Rights was derailed at the Commission's $59^{\text {th }}$ session held in April 2003 by a coalition of Muslim countries. This highlights what a sensitive and difficult subject this can be to reach agreement on at the international level. The meeting is reported at UN Doc. E/CN.4/2003/SR.63.

8 Howard-Hassmann, R., 'Gay Rights and the Right to a Family: Conflicts Between Liberal and Illiberal Belief Systems', Human Rights Quarterly, Vol. 23, No. 1, 2002, pp. 73-95, at p. 74

9 The exception has been the European Commission on Human Rights and European Court of Human Rights, about which see below. 


\subsection{The Position within the United Nations}

Article 23(1) of the International Covenant on Civil and Political Rights (ICCPR) expressly provides for the positive protection of the family. It states that the family is the natural and fundamental group unit of society and is entitled to protection'. The Human Rights Committee (HRC), the body created to monitor compliance with that treaty, has remained largely untroubled by the need to further define the terms of this article, adopting a flexible interpretation of 'the family' based on the State's own definition. In its General Comment on this article the HRC has said that

'the concept of the family may differ in some respects from State to State, and even from region to region (...) it is therefore not possible to give the concept a standard definition. ${ }^{10}$

The HRC concluded that 'the family' should be defined by domestic laws, and only then must this unit of people be offered special protection. Given the wide range of States that are party to the ICCPR it is, perhaps, unsurprising that the $\mathrm{HRC}$ has not rushed to offer a dynamic interpretation of this provision. However, the obvious consequence of this approach is that States do not have to offer protection to same-sex relationships if they choose not to. Furthermore, in its General Comment the HRC went on to say that the right to found a family 'implies, in principle, the possibility to procreate and live together'. "' This at least suggests that the 'family' of the ICCPR is presumed to be a heterosexual unit.

This suggestion is also supported by the heterosexist language of Article 23(2), which affirms the 'right of men and women of marriageable age to marry and to found a family'. That this provision does not extend to samesex couples was confirmed in the recent case of Joslin vs New Zealand. ${ }^{12}$ This case was brought by two co-habiting and co-parenting lesbian couples who had been denied a marriage licence under New Zealand domestic laws. They challenged this (unsuccessfully) in domestic courts and subsequently lodged a communication with the HRC, primarily arguing that their rights under Article 23 of the ICCPR had been violated. The HRC held:

'Use of the term "men and women" (...) has been consistently and uniformly understood as indicating that the treaty obligation of States parties stemming from article 23, paragraph 2, of the Covenant is to

\footnotetext{
10 Human Rights Committee, General Comment $19,39^{\text {th }}$ Session, 1990. UN Doc. HRl/GEN/1/ Rev.1, at 28 , at para. 2.

1 Ibidem, at para. 5.

12 Joslin vs New Zealand, Comm. 902/1999, 30 July 2002. UN Doc. CCPR/C/75/D/902/1999. Details of this case are given by Christie, N., 'The New Zealand Same-Sex Marriage Case: From Aotearoa to the United Nations', in: Wintemute, R. and Andenas, M. (eds.), Legal Recognition of Same-Sex Partnerships, Hart, Oxford, 2000, at pp. 317-335.
} 
recognize as marriage only the union between a man and a woman wishing to marry each other. ${ }^{, 13}$

The reticence of the $\mathrm{HRC}$ to interfere in how States positively protect relationships does not extend to situations where there has been a negative violation of rights. The HRC has had the opportunity to consider a case involving the discriminatory criminalisation of gay male sexual activity in Tasmania. In the case of Toonen vs Australia ${ }^{14}$ arguments were heard in relation to interference with the applicant's right to privacy. The HRC found that the regulation by States of gay sexual behaviour was a legitimate matter for their consideration:

The Committee cannot accept that for the purposes of Article 17 of the Covenant, moral issues are exclusively a matter of domestic concern, as this would open the door to withdrawing from the Committee's scrutiny a potentially large number of statutes interfering with privacy. ${ }^{15}$

The HRC, however, restricted its decision to the right to privacy and sexual equality. The decision therefore does not have any obvious implications for the positive protection of same-sex relationships, although it does suggest an unfortunate collusion with the notion that they are somehow shameful and private matters. This treatment of gay relationships as 'private matters' was also suggested by the HRC's consideration of Zimbabwe's initial periodic report in 1998. In its report Zimbabwe stated that homosexuals could be expelled from the country on the basis of their sexuality. The HRC responded by describing this as a violation of the right to privacy. ${ }^{16}$ Of course this was an important pronouncement, but by focussing again on the issue of privacy it tends to deny recognition to those relationships that might thereby be affected. The message of the HRC seems clear: gay relationships must be tolerated but they do not have to be recognised, nor offered protection or equality of treatment.

Developments within the United Nations towards protecting the rights of women have done little to benefit lesbians in matters concerning their relationships. Member States of the 1979 Convention on the Elimination of all Forms of Discrimination Against Women (CEDAW) condemn discrimination 'against women in all its forms' ${ }^{17}$ and yet the Convention deals with discrimination based upon gender only. In relation to 'the family' CEDAW provides for the elimination of 'discrimination against women in all matters relating to marriage and family (...) on a basis of equality of men and women'. ${ }^{18}$ The irrelevance of this provision to lesbian families is obvious.

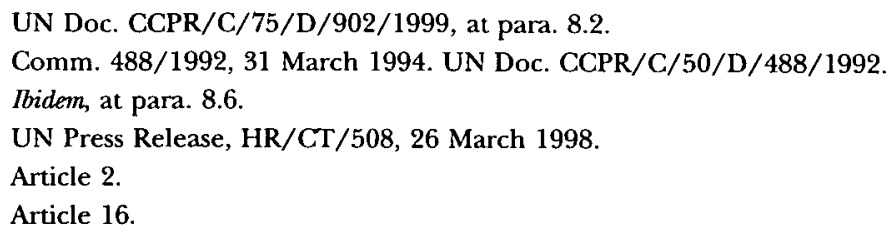


There was an attempt made by Canada during the 1995 Fourth World Conference on Women, held at Beijing, to include 'sexual orientation' within the final statement. Several delegates supported this suggestion and the draft 'Platform of Action' that was initially presented to the conference contained four references to sexual orientation. However, by the time that the 'Platform of Action' was finalised, all references to sexual orientation had been eliminated.

\subsection{The Position within Europe}

The treaty monitoring body of the European Convention on Human Rights (ECHR) is currently the European Court of Human Rights (ECtHR). This single-body system replaced the two-tier system of the Court and a European Commission on Human Rights (ECmHR) pursuant to Protocol 11 coming into force in November 1998. Both these bodies have shown little reticence in determining which relationships should be accorded family status and accorded protection under Article 8 of that convention, which contains the right to respect for 'private and family life, his home and his correspondence'. In doing so they have adopted an expansive definition of the family that reflects many of the social and legal developments that have occurred in the Member States since the ECHR came in to force. For example, in the case of Marckx vs Belgium ${ }^{19}$ the ECtHR found that discrimination against illegitimate children in terms of legal recognition of their relationship with their mothers was contrary to Article 8 . They said that any such 'distinction would not be consonant with the word "everyone" that is used in Article $8 .^{20}$ The Court went on to recognise that 'there may be positive obligations inherent in an effective "respect" for family life'. ${ }^{21}$ Likewise, the ECtHR and the ECmHR have found that family life includes the relationship between an illegitimate child and father ${ }^{22}$ as well as that between child and adoptive parents, ${ }^{23}$ grandparents, ${ }^{24}$ and even an uncle with whom the child had had frequent contact. ${ }^{25}$ Furthermore it has been held that familial relationships do not end on divorce. ${ }^{26}$

As with the HRC, the first cases involving discrimination against homosexuals that were considered by the ECHR monitoring bodies involved discriminatory treatment of gay male sexual activity under the criminal

\footnotetext{
19 Marckx vs Belgium, Series A 31 (1979).

$20 \quad$ Ibidem, at para. 31.

21 Idem

$22 \quad$ Keegan vs Ireland, Series A 290 (1994).

$23 X$ vs France, Appl. No. 9993/82, 31 DERR 241 (1982).

24 Price vs the UK, Appl. No. 12402/86, 55 DER 224 (1998).

25 Boyle vs the UK, Series A 282-B Com Rep (1994).

26 Berrehab vs the Netherlands, Series A 138 (1988).
} 
law. ${ }^{27}$ In the case of Dudgeon vs the United Kingdom ${ }^{28}$ the ECtHR held that the criminalisation of sexual acts between men was an interference with 'a most intimate aspect' of the applicant's private life, protected under Article $8 .^{29}$ The need for positive protection of gay relationships has, however, not been recognised by the Strasbourg machinery. In the case of $X$ and $Y$ vs the United Kingdom ${ }^{30}$ a gay male couple, one Malaysian and one British, argued that denying the Malaysian applicant a residence permit in the United Kingdom was an interference with their family life. The ECmHR, in declaring the case to be inadmissible, held that:

'Despite the modern evolution of attitudes towards homosexuality, the Commission finds that the applicant's relationship does not fall within the scope of the right to respect for family life ensured by Article 8.,31

The ECmHR considered the issue as a question of private (as opposed to family) life and consequently found that the couple were not entitled to be granted permission to establish a relationship in any particular country. This contrasts rather sharply with, for example, the case of Berrehab vs the Netherlands, ${ }^{32}$ in which the Moroccan applicant was found to have had his right to family life breached in not being granted permission to stay in the Netherlands where his daughter of Dutch nationality resided. The decision in $X$ and $Y$ vs the United Kingdom was taken in 1983, and has had an enormous impact on the treatment of gay relationships ever since. It meant that the ECmHR declared every subsequent case before it involving positive discrimination against same-sex couples inadmissible. For instance in the case of Simpson vs the United Kingdom ${ }^{33}$ the applicant had been co-habiting with her lesbian partner for nearly four years. On the death of her partner, the applicant was evicted from the council home in which they had been living. Had they been an unmarried heterosexual couple she would have been protected under the tenancy. The ECmHR held that as a same-sex couple there could be no question of interference with family life, and that as her partner was dead there could be no question of interference with her private life! They went on to explain the difference in treatment as being

$27 \quad$ See, for example, Dudgeon vs the UK, Series A 45 (1981); Norris vs the UK, Series A 142 (1988); Modinos vs Cyprus, Series A 259 (1993); A.D.T. vs the UK, Appl. No. 35765/97, judgment of 31 July 2000; and the ECmHR's report in Sutherland vs the UK, Appl. No. 25186/94, 1 July 1997.

28 Idem.

29 Ibidem, at p. 21.

so $X$ and $Y$ vs the United Kingdom, Appl. No. 9369/81, 32 DERR 220 (1983). See also W.J and D.P vs the UK, Appl. No. 12513/86, decision of 13 July 1987 and Z.B vs the UK, Appl. No. 16106/90, decision of 10 February 1990.

31 Ibidem, at p. 221.

32 Berrehab vs the Netherlands, loc.cit. (note 26).

33 Simpson vs the United Kingdom, Appl. No. 11716/85, 47 DÉFR 274 (1986). 
justifiable as the family 'merits special protection in society', and therefore the discrimination could be 'objectively and reasonably justified'. ${ }^{34}$

It would not be true to say that the important distinguishing feature of Berrehab, ${ }^{35}$ cited above, is the fact that the case concerned the relationship between an adult and a child. For example, in the case of Kerkhoven vs the Netherlands ${ }^{36}$ the applicants, a lesbian couple, complained of an interference with their family life as the first applicant (the non-biological mother) could not be given parental authority over their child (conceived by artificial insemination), meaning that there were no legal ties between her and her child. Had they been a man and a woman this would have been possible. The ECmHR reiterated that homosexual people could not form a family, and noted that 'as regards parental authority over a child, a homosexual couple cannot be equated to a man and a woman living together'. The ECmHR said that there was no positive responsibility on States to protect relationships involving same-sex couples. In the similar case of $C$ and L.M vs the United Kingdom, ${ }^{37}$ the first applicant was an Australian citizen who had become pregnant by artificial insemination whilst living in a lesbian relationship in the United Kingdom. Parenting was shared between the two women, they jointly owned a property and the applicant was financially dependent upon her partner. The applicant's deportation had been ordered as her residency rights in the UK had expired and she complained that this amounted to an interference with her family life. Once again, the ECmHR repeated that the couple and their child could not form a family, and they therefore could not interfere with the deportation order. That the ECmHR did not hear any further cases involving gay relationships in the last nine years of its life will come as little surprise.

Since the ECtHR has taken over questions of admissibility (following the abolition of the ECmHR under Protocol 11) we have yet to see any concrete evidence that it is taking a more critical and progressive approach towards recognising same-sex relationships. A case that appears initially to be promising is that of Salgueiro da Silva Mouta vs Portugal. ${ }^{38}$ The applicant was a man living in a gay relationship, seeking parental responsibility of his daughter ('M.') from his previous marriage. Initially the Lisbon Family Affairs Court found the applicant to be the most fit parent and M. therefore went to live with him. This decision was reversed on appeal, as the Lisbon Court of Appeal said that the first principal is that young children should not be separated from their mother. They went on to say that social values should be taken into account when establishing what is in the best interests of the child, and found:

\footnotetext{
$34 \quad$ Ibidem, at p. 279.

35 Berrehab vs the Netherlands, loc.cit. (note 26).

36 Appl. No. 15666/89, decision of 19 May 1992.

37 Appl. No. 14753/89, decision of 9 October 1989.

$\mathbf{3 8}$

Salgueiro da Silva Mouta vs Portugal, Reports 1999 - IX.
} 
'[I]t cannot be argued that a [homosexual environment] is the healthiest and best suited to a child's psychological, social, and mental development, especially given the dominant model in our society (...) In both cases it is an abnormality and children should not grow up in the shadow of abnormal situations...'

The applicant was still allowed contact with M., although the Court of Appeal said that it

'should be impressed upon the father that during these periods he would be ill advised to act in any way that would make his daughter realise that her father is living with another man in conditions resembling those of man and wife.'

The ECtHR held that this amounted to discrimination under Article 14 (which prohibits discrimination in relation to the enjoyment of the Convention's rights) in combination with Article 8 as the Court had treated the applicant and his former wife differently on the basis of his sexuality. However it is significant that this case does not affect how 'family' is defined. As the applicant was the biological father of his daughter, it was taken for granted that there was a familial relationship between them. It was discrimination on the basis of his subsequent choice of partner that was held to be unacceptable.

It seems that the ECtHR is not yet prepared to view same-sex relationships (and any children born into these relationships) as 'the family' that the ECHR seeks to protect. This was suggested by the recent case of Fretté vs France, ${ }^{39}$ in which a gay man challenged a decision of the Conseil $d^{\prime} E t a t$ to dismiss his request to be granted preliminary leave to adopt a child. Under French law, unmarried men and women are eligible to be adopters, and the refusal of Mr Fretté's application was made largely on the basis that his homosexuality made him an unsuitable person to bring up a child. In its judgment of 26 February 2002, the ECtHR held, by four votes to three, that there was no violation of Article 8 (in conjunction with Article 14) in this respect. The basis of this decision was that the reasons for the refusal were legitimate (promoting the best interests of children) and proportionate. The Court cited, in this respect, the lack of agreement amongst Member States about the recognition of gay relationships, the lack of scientific agreement about the effect on children of being brought up by a gay person (or gay couple). The Court determined that this uncertainty meant that Member States must have a wide margin of appreciation in deciding where the best interests of children awaiting adoption lie.

The Court's most recent judgment in relation to this issue, however, offered some suggestion that it may be becoming more receptive to the idea 
that same-sex relationships merit protection. The case of Karner vs Austria concerned the non-recognition of the applicant's right to succeed to his male partner's tenancy on his death, which he would have been entitled to do if recognised as a family member. The Court used strong language in finding a violation of Article 8 , holding that only a narrow margin of appreciation exists in relation to discriminatory treatment that is based on sexual orientation. However, it was notable that the Court did not consider the application on the basis of respect for the applicant's family life (which was clearly at the heart of the case) and chose instead to focus on the right to respect for the applicant's home. Whilst one can be cautiously optimistic about the potential impact of this case on the future recognition of same-sex relationships in Europe, it is clearly significant that the Court deliberately avoided discussing this case in the context of the right to respect for family life.

The ECHR also provides under Article 12 that 'men and women of marriageable age have the right to marry and to found a family', which has been held to apply to unions of opposite sexes only. Interestingly, this interpretation of Article 12's language has been questioned in a series of cases that have been brought by transsexuals wishing to have their new gender recognised. The recent judgment of Coodwin vs the United Kingdom was remarkable for its refreshingly open attitude to transsexual issues:

'The Court is not persuaded that at the date of this case it can still be assumed that these terms must refer to a determination of gender by purely biological criteria (...) There have been major social changes in the institution of marriage since the adoption of the Convention as well as dramatic changes brought about by developments in medicine and science in the field of transsexuality. ${ }^{41}$

This was a notable volte-face from the Court's earlier jurisprudence on this issue. ${ }^{42}$ However, this judgment does not necessarily offer comfort for those seeking similar rights for those in a same-sex relationship. The rationale for recognising Ms Goodwin's right to marry was that the Court recognised her new gender. In other words, her relationship with a man was equated with a heterosexual relationship. This is not a signal that the Court is yet prepared to recognise homosexual relationships. That the ECtHR still takes a heterosexist view of Article 12 was confirmed in the recent admissibility decision of Fretté vs France, mentioned above. ${ }^{43}$ The applicant in this case also complained of a violation of his right to found a family. The Court declared

40 Karner vs Austria, Appl. No. 40016/98, judgment of 24 July 2003.

41 Goodwin vs the United Kingdom, Appl. No. 28957/95, judgment of 11 July 2002, at para. 100.

42 See Rees vs the UK, Series A 106 (1986). See also Cossey vs the UK, Series A 184 (1990) and Sheffield and Horsham vs the UK, Reports 1998 - V. 
this part of the application inadmissible, reiterating that 'l'article 12 de la Convention se borne à garantir le droit de se marier à l'âge nubile à deux personnes de sexes biologiques différents' ${ }^{44}$

There has also been a Council of Europe Parliamentary Assembly Recommendation that 'the role of the state' is not to create family policy with

'hard and fast replies based on ideology, but to create the circumstances necessary for the establishment of a family unit in which the individual can develop in safety, solidarity and respect for fundamental rights' ${ }^{45}$

However, the ECtHR has not yet played a role in ensuring that this vision becomes a reality for those in same-sex relationships.

\subsection{The Position under Other Regional Human Rights Treaties}

Although there has been very little discussion of the concept of 'family' under the other regional treaties, it seems safe to assume that it has been understood to refer to units based on heterosexual unions. This seems a particularly fair assumption to make in light of Article 18 of the 1981 African Charter on Human and Peoples' Rights, which describes the family as the 'custodian of morals and traditional values' ${ }^{46}$ Given the grave human rights abuses that the Commission has had to consider, it is not surprising that it has not delivered any decisions involving the protection of same-sex relationships under Article 18 of the Charter. A petition was submitted to the African Commission on Human and Peoples' Rights seeking an investigation into Zimbabwe's laws and policies on homosexuals, but this was subsequently withdrawn. ${ }^{47}$ A collection of the Commission's decisions reveals that its time has been taken up with issues such as false imprisonments, rather than defining what 'the family' of Article 18 refers to. ${ }^{48}$

Neither have the treaty-monitoring bodies of the Inter-American human rights system given any decision as to whether same-sex relationships actually come under the definition of 'the family' to this author's knowledge, nor have they said much about their understanding of 'family'.

\footnotetext{
$44 \quad$ Idem (available in French only).

45 Parliamentary Assembly of the Council of Europe, Recommendation 1074 (1988) on family policy.

46 Article 18.

47 136/94 A Courson vs Zimbabwe. This case is reported in Dunton, C. and Palmberg, M., Human Rights and Homosexuality in Southern Africa, Nordiska Afrikainstituet, Uppsala, 1996, at p. 44.

48 In a collection of the Commission's decisions from 1994-1999 only one case refers to Article 18, in relation to expulsion of West African nationals from Angola. Communication 159/96 published in: Compilation of Decisions on Communications of the African Commission on Human and Peoples' Rights Extracted from the Commission's Activity Reports 1994-199, Institute for Human Rights and Development, Banjul, 1999.
} 
Again, much of the time of the Inter-American Court of Human Rights and Inter-American Commission on Human Rights has been taken up with dealing with cases involving extreme violations of rights, such as disappearances. However, the family is protected both under Article 11 of the 1969 American Convention on Human Rights (ACHR) and Article 6 of the American Declaration of the Rights and Duties of Man, 1948. Davidson suggests that whilst the language of the 1948 Declaration 'would seem to contemplate the possibility of single parent families and same-sex parent families', nevertheless 'the instruments appear to support the traditional concept of family'. ${ }^{49}$ One case suggests that a similar route is being taken before the Inter-American bodies as before the other human rights tribunals discussed above. In a case awaiting decision by the Commission, Marta Lucia Álvarez Giraldo vs Colombia ${ }^{50}$ the petitioner, a prison inmate, complained of the prison authority's refusal to allow her lesbian partner intimate visits, a right allowed to heterosexual couples. The Commission found the case to be admissible on the grounds that it could constitute an interference with her private life under Article 11(2) of the ACHR. Once again, this suggest that situations involving the disruption of or interference with same-sex couples will be viewed as a matter of private life, rather than family life, and therefore will not attract the same requirement of positive protection.

\section{WHY SHOULD INTERNATIONAL AND REGIONAL HUMAN RIGHTS TRIBUNALS RECOGNISE GAY RELATIONSHIPS?}

We have seen that international human rights treaties do not offer specific protection to same-sex relationships, neither have their supervisory bodies interpreted the term 'family' to encompass such relationships. It is therefore fair to conclude that international and regional human rights treaties offer better protection to heterosexual relationships than to homosexual relationships. Human rights lawyers must, therefore, take responsibility for rigorously and continuously scrutinising this decision to ensure that the discrimination against gay relationships is both justifiable and necessary. Because by being denied the possibility of 'family' status, and the positive protection that comes with that status, gay couples are being denied many rewards. Of course the rewards differ from country to country and will depend on domestic legislative provisions, but several possible areas of discrimination can be readily identified. We have seen some examples of the difficulties faced by gay couples in the case law discussed above. Ryder has

49 Davidson, S., 'The Civil and Political Rights Protected in the Inter-American Human Rights System', in: Harris, D. and Livingstone, S. (eds), The Inter-American System of Human Rights, Clarendon Press, Oxford, 1998, at p. 270. 
identified several areas within which gay couples who do not have legal recognition might suffer discrimination. ${ }^{51}$ Amongst these are:

- pension rights;

- employment benefits;

- benefits on death or injury;

- income tax;

- the ability to marry, which might bring religious and social, as well as legal, disadvantages;

- entitlement to property after separation;

- entitlement to support after separation;

- custody and access to children;

- intestacy;

- tort rights;

- immigration;

- under criminal law.

I would add to this list adoption rights and the receiving of fertility treatment in which gay couples are frequently discriminated against. In fact, the discrimination suffered by same-sex couples happens in numerous ways that cannot be readily listed. By being denied the same rights as heterosexual couples, people in gay relationships suffer tangible discrimination in every country in the world. Therefore cogent and persuasive reasons for this discrimination must be given and it is submitted that they cannot. As we have seen above, as a general rule international and regional human rights tribunals have either not chosen to, nor had the opportunity to, give consideration to this matter. It is submitted that it is important that international and regional tribunals do engage in this debate. In the meantime, some of the arguments that might be given in support of discriminating against gay relationships shall now be considered, and their potential inadequacies discussed.

\subsection{The Natural Order}

One powerful argument in favour of the current heterosexist interpretation of human rights treaties is that it is consistent with the natural order of things and certainly in some domestic cases judges have been persuaded by arguments that same-sex relationships are denied legal status because they are offensive to morality. For example in 1986 the US Supreme Court in Bowers vs Hardwick ${ }^{52}$ suggested that 'millennia of moral teaching' could protect sodomy laws against due process attack, arguments that presumably would apply to discrimination in family matters. And it is almost certainly

\footnotetext{
51 Ryder, B., 'Equality Rights and Sexual Orientation: Confronting Heterosexual Family Privilege', 9 Canadian Journal of Family Law, 1990, p. 39, at p. 49.

52 Bowers vs Hardwick, 478 US 186 (1986).
} 
true that the drafters of all the human rights treaties mentioned above had a heterosexual, and probably married, unit in mind when they spoke about protecting 'the family'. As Howard-Hassmann says, even if we try and interpret the loose language of the treaties to incorporate gay relationships, this is unlikely to be consistent with the intention of the drafters:

'[W] hile this may be a useful legal point in arguing for the rights of gays and lesbians to marry, it is sociologically anachronistic to assume that the drafters and original signers of the UDHR did not have in mind a heterosexual family. ${ }^{.53}$

But of course, that is precisely the strength and success of the human rights treaties discussed above, that they have been interpreted in ways consistent with shifting social mores. So we are free to consider this argument about whether heterosexual families form part of an exclusive natural order in light of our current understandings.

Firstly, the historical argument that says that heterosexual relationships are the only relationships that have been historically protected and respected has been shown to be inaccurate. Evidence now suggests that for many centuries homosexual relationships have not only taken place in several different societies throughout the world, but also have been recognised and respected. In his study of the history of same-sex relationships, Eskridge concluded that these relationships can be traced to all the early civilisations. ${ }^{54} \mathrm{He}$ cites the example that the early Egyptian and Mesopotamian cultures 'not only tolerated same-sex relationships, but also recognised such relationships in their culture, literature and mythology'. ${ }^{55}$ Furthermore he finds evidence of same-sex marriage in Greek and early Roman culture as well as in Western Europe for mush of the Middle Ages. ${ }^{56}$ Eskridge also finds 'very strong evidence' of legally recognised unions in Native American, African and Asian cultures. ${ }^{57} \mathrm{He}$ found that people involved in same-sex relationships have been leaders of their communities, citing the 19th century example of Ifeyinwa Olinke, a powerful woman of the Igbo tribe from Eastern Nigeria, whose names referred to the fact that she had nine wives. Far from being a modern anachronism, gay relationships have formed part of the fabric of many societies over many centuries. In fact, in many cases legal prescriptions can be traced to the 13 th century in Western countries that were later introduced into the colonies. ${ }^{58}$

\footnotetext{
53 Howard-Hassmann, loc.cit. (note 8), at p. 74 .

54 Eskridge Jnr, W., 'The History of Same-Sex Marriage', 79 Virginia Law Review, 1993, p. 1419.

$55 \quad$ Ibidem, at p. 1437.

56 Idem.

$57 \quad$ Ibidem, at p. 1453.

$58 \quad$ Ibidem, at p. 1469.
} 
In any event, the international community ought to be wary of any ideology that offers a permanent prescription of moral superiority of one group over another. That the 'natural order' in the United States was said to prohibit interracial marriages should alert us when we hear these kinds of arguments in relation to same-sex relationships. We are intellectually free to reject any superstitiously prescribed beliefs that are stated without justification. The concept of 'family' is a legal and social construct, rather than stemming some inexplicable static 'natural order'. As Ryder notes:

'The amount of legal architecture that has gone into building the ideal family and supporting heterosexuality is staggering - hundreds of pieces of legislation, thousands of regulations, rules, by-laws and judicial decisions. This plethora of government activity promotes the idea that there is only one legitimate family form, and thus ensures that all those people living outside these legally and ideologically created norms are constructed as deviant. ${ }^{, 59}$

And of course cultural morality and social mores are constantly developing. Feminists have long had to argue for reinterpretations of cultural practices when these discriminate against women. It seems clear that gay people are going through the same process, and it is imperative that international human rights tribunals continuously question whether the moral standards that discriminate against gay relationships are acceptable and legitimate. Human rights lawyers should therefore be vigilant against any arguments that the definition of family inherently excludes same-sex couples, ${ }^{60}$ and that heterosexual relationships are part of a 'natural order' that is globally recognised. As the US Supreme Court held in the Lawrence vs Texas case in which they overturned the Bowers vs Hardwick decision on sodomy laws, 'Bowers was not correct when it was decided, and it is not correct today' ${ }^{61} \mathrm{We}$ should be able to rid ourselves of prejudice and evaluate gay relationships on their merits.

\subsection{Families Create Children}

Another argument used to justify giving preference to heterosexual relationships is that a 'family' is comprised of a couple who are able to have children; heterosexual relationships are preferred as their purpose is to fulfil this fundamental social need. Certainly Howard-Hassmann believes that this is an argument that cannot be easily overlooked in relation to African cultures in which all adults have a responsibility to reproduce:

\footnotetext{
$59 \quad$ Ryder, loc.cit. (note 51), at p. 47.

60 See, for example the Kentucky Court of Appeal decision in Jones vs Hallahan, 501 SW.2d 588 (Ky.1973), where the inherent definition argument was accepted.

61 Bowers vs Hardwick, judgment of 26 June 2003, Case No. 02-102, at p. 21.
} 
'Despite the economic and ecological changes that make advisable a reduction in fertility rates, all adults bear a social responsibility to marry and have children (...) Even in societies with ritualized homosexual activities, the family unit is still preserved. The adult male is expected to marry and procreate, even if his emotional ties are still to men. ${ }^{62}$

But even if this argument can be said to be applicable to all modern African cultures, we must be aware that the tide of change, in whatever direction it takes, can and will come. As feminists know, it is too easy to put discriminatory practices down to tradition and to ignore the possibility for changing cultural patterns.

Clearly the argument that heterosexual partnerships are to be preferred because they create children quite simply ignores the fact that many opposite sex couples are either unable to have children or do not want to have them. Furthermore, many 'families' are not made up of biological children, rather adopted children, stepchildren, grandchildren and so on. It has been seen that these types of relationships have been recognised as familial by international human rights tribunals. There seems, therefore, no good reason to exclude gay relationships on this basis. In any event, it is submitted that it is preferable to take a pragmatic and realistic approach. The fact is that many gay coupes are having children, despite the laws frequent unwillingness to recognise this. There are now opportunities for women in lesbian relationships to have IVF treatment or to self-inseminate; a gay male couple may arrange to have a child with the help of a surrogate mother; there may be children from a previous heterosexual relationship; or there may be the possibility of adoption or fostering of children. It is in everyone's interests to provide a legal framework for these relationships, and in particular it is surely in the best interests of any children concerned.

\subsection{The Best Interests of the Child}

If we accept that people in gay relationships are actually having children and are looking after children, international law doubtless would wish to consider whether these relationships are in the best interests of the child. Minow even argues that the ultimate test of a 'family' ought to be dictated by the best interests of the child. ${ }^{63}$ Clearly these relationships need to be brought within a human rights framework before any such analysis can take place. However, caution should be exercised not to allow prejudice to inform the debate. In the past such discussions have disadvantaged lesbian mothers in domestic courts. For example, in the 1994 South African case

\footnotetext{
62 Howard-Hassmann, loc.cit. (note 8), at pp. 87-88. 
Van Rooyen vs Van Rooyen the access of a lesbian mother to her children was subject to the condition that her partner stayed in a separate bedroom at weekends when the children visited, and that she stayed elsewhere during holiday visits. The court explained their decision in the following way:

'The signals are given by the fact that the children know that, contrary to what they should be taught as normal or what they should be guided to as to be correct (that it is a male and female who share a bed), one finds two females doing this (...) as a matter of preference and a matter of mutual emotional attachment (...) It is detrimental to the child because it is the wrong signal. ${ }^{64}$

Even in cases where a lesbian has been granted custody of a child there are occasions when the court has made it clear that this is a 'second best' option for the child. For example in the United Kingdom case of $C$ vs $C$ (A Minor) ${ }^{65}$ Glidewell LJ held that it was 'axiomatic' that a child ought to be brought up in a home that most closely represents a heterosexual nuclear family.

International human rights law must provide an objective interpretation of what is in the best interests of the child and must guard against making the assumption this is best served by a nuclear heterosexual family. Recent research by Dunne, for example, has shown that lesbian couples make effective parents and lesbians are in many cases successful in achieving equality and balance in relation to housework and childcare ${ }^{66}$ Furthermore, in their review of studies on the effects on children of being raised by lesbian mothers, Tasker and Golombok conclude:

'Empirical evidence demonstrates that the mother's sexual orientation does not appear to influence the child's well-being. Legal decisions concerning where the child should reside post-divorce should focus instead on the quality of parenting, ${ }^{, 67}$

And there is some evidence that this research is influencing the attitudes of lawmakers. For example Dame Elizabeth Butler-Sloss was quoted at her first press conference as president of the High Court of England and Wales' Family Division as saying that she had been, 'dubious about the stability of children living in a family with two parents of the same sex. But over the years research has shown that for some children, that is the best that is

\footnotetext{
$64 \quad$ Van Rogyen vs Van Rogyen, 1994 (2) SA 325(w), at 329I - 330-B

65 C vs C (A Minor), [1991] 1 FLR 223.

66 Dunne, G., 'Balancing Acts: Lesbian experience of work and family life', in: Sperling, L. and Owen, M. (eds), Women and Work: The Age of Post-Feminism?, Ashgate, Aldershot, 2000, pp. 109. 132.

67 Tasker, F. and Golombok, S., 'Children Raised by Lesbian Mothers', 21 Family Law, 1991, p. 184 , at p. 187 .
} 
available for them'. ${ }^{68}$ Therefore there would seem to be little evidence on which international human rights law should deny family status to gay partners and their children because of any possible detriment to the children involved.

\subsection{Contrary to Global Trends}

Human rights law is not best served by taking a strictly positivist and Statecentred approach and it must be able to say when necessary that the social norms of a State are unnecessarily discriminatory. One can see the influence of this view, for example, in the UN Committee on the Elimination of Discrimination against Women's assertion that measures must be taken to abolish discriminatory cultural practices. ${ }^{69}$ If it were otherwise international human rights would simply provide affirmation of the dominant ideology. What human rights law must do, therefore, is to assess cultural practices in a sensitive and objective way. The most important thing is to recognise in relation to gay relationships that there is a human rights issue to resolve that should not be ignored by international and regional human rights tribunals. That said it certainly adds strength to our argument if we can point to progress and developments at the domestic level that are not being mirrored by international and regional human rights bodies. There are increasing numbers of States, particularly in Western Europe, that now recognise samesex relationships in one form or another. There is a very real danger that the international and regional human rights tribunals may not only be failing to set standards in this area, but also falling behind the standards being set at the domestic level. The developments that have occurred at the domestic level should be affirmed by the international community.

It is important to stress that the issue of gay relationships is not a matter of concern only in Western States, although as mentioned above, it is true to say that amongst the Member States of the Council of Europe there has been the greatest recognition of these relationships in law. This is an issue affecting gay people throughout the world, and it is important that human rights law does not continue to remain outside of the dialogue that is taking place globally concerning legal recognition of same-sex relationships. Clearly to give a comprehensive overview of the situation of same-sex couples throughout the world is not within the scope of this essay and the laws in this area are rapidly developing. However it ought to be sufficient to note that in recent years there have been significant examples of both legislative and judicial developments towards legal recognition of same-sex relationships, and there are also movements in many countries with this as their aim. A broad overview of some of these domestic developments will now be given to give an idea of the scale and speed of the changes taking

The Guardian, 16 October 1999, p. 2.

Article 2 CEDAW. 
place in relation to the recognition of same-sex relationships in certain countries.

\subsubsection{Europe}

At least within the context of the Council of Europe Member States there is a developing consensus that same-sex couples ought to be recognised, and there have been significant legislative developments that go some way to achieving this. ${ }^{70}$ The Netherlands, where gay couples have been able to have a civil marriage ceremony since 1 January 2001 , became the first country in the world to recognise same-sex marriages. ${ }^{71}$ This was followed in Belgium, where marriage became open to same-sex couples in January $2003 .^{72}$ In Denmark ${ }^{73}$, Sweden, ${ }^{74}$ Norway, ${ }^{75}$ and Iceland ${ }^{76}$ legislation has been in force for several years to provide for greater equality for same-sex couples, which in most cases provides for similar rights to married couples. ${ }^{77}$ The Nordic countries have mutually recognised each other's acts since August 1995. In September 2001 Finland adopted similar legislation, which came into force in March 2002. Since November 1999 gay couples in France have had available to them a form of recognition of their relationship under the 'civil solidarity pacts'. These fall short of the recognition offered to married couples, but they do offer certain tax, inheritance and social security benefits. The Portuguese Parliament passed legislation in March 2001, which recognise same-sex unions in a similar way to the French system, and

70 For much of the information in this section I am indebted to the ILGA-Europe Report, Equality for Lesbians and Gay Men: A Relevant Issue in the Civil and Social Dialogue, June 1998, available at www.steff.suite.dk/report.htm (accessed 11 November 2003).

The principal differences remaining between heterosexual and same-sex marriages are that same-sex couples are not allowed to jointly adopt children from overseas and that their relationships are not recognised for the purpose of international agreements.

The provisions relating to adoption remain less favourable for same-sex couples than for heterosexual couples.

Registered Partnership Act No. 372, in force 1 October 1989. The law applies to Danish citizens or citizens of countries with similar legislation or to two foreigners who have lived in Denmark for two years. This law was amended in 1999 to allow for a registered partner to adopt the child of his/her partner unless the child is adopted from a foreign country. Under the legislation adoption of foreign children is not possible and artificial insemination of a registered lesbian couple is not possible. All information from www.steff.suite.dk/ partner.htm.

74 Law on Registered Partnership, SFS 1994:1117, in force 1 January 1995. This contains similar provisions to that of Norway (see below) but since July 2000 foreigners who have lived in Sweden for two years can be registered.

75 Law on Registered Partnership, in force 1 August 1993. The legislation applies only to Norwegian citizens living in Norway and does not allow for adoption of children by a registered couple.

76 Registered Partnership Law, 27 June 1996. Similar legislation to that of Norway, although it does allow for joint custody of children.

77 These, however, have not provided for the right to adopt. Danish legislation has been amended to include this right. Diva Magazine, July 1999, p. 28. 
in Germany registering same-sex unions has been possible since 1 August 2001. Similar legislation is being considered in the Czech Republic, Luxembourg, Spain and Switzerland.

Within common law countries there have been judicial developments that have led to changes in the legal status of same-sex relationships. In a 1995 decision of the Hungarian Constitutional Court it was declared that the lack of recognition of same-sex relationships was unconstitutional. ${ }^{78}$ Following this decision, the law that had regulated the property of (unmarried) people living in the same household was amended to include same-sex relationships in May 1996. In the United Kingdom it has been held that a lesbian living with her partner may adopt a child placed with her by the local authority, ${ }^{79}$ despite the objections of the natural mother. In that case the judges strongly rejected the view that there was any rule excluding lesbian or gay adoption. More recently in $G$ vs $F^{80}$ leave was granted for a non-biological lesbian mother to apply for a shared residence order of her child on the ending of her relationship with the biological mother. In Fitzpatrick vs Sterling Housing Association, ${ }^{81}$ which concerned a gay male's ability to succeed his long-term partner's tenancy under the terms of the Rent Act 1977, the House of Lords held that the relationship could be recognised as familial for that purpose. Waite L.J, in the Court of Appeal hearing of that case, referred to the 'spirit of our times (...) which recognises the value of all abiding relationships, the heterosexuals, the lesbian, the gay, or even those which are not sexually based at all'. ${ }^{82}$

In the United Kingdom immigration rules for homosexual couples have been amended to reduce the length of time to two years that same-sex couples have to have been co-habiting before being granted permission to reside in the country. ${ }^{83}$ Most significantly, in November 2003 the Government proposal for the legal recognition of same-sex partnerships in England and Wales was included in the Queen's Speech. With these developments in mind, the judgments of the ECtHR discussed above are beginning to appear very out of touch.

\subsubsection{The Americas}

In the Canadian Charter of Rights and Freedoms case of Egan vs Canada ${ }^{84}$ concerning discrimination against a same-sex couples under the Old Age

\footnotetext{
78 See Farkas, L., 'Nice on Paper: The Aborted Liberalisation of Gay Rights in Hungary', in: Wintemute and Andenas, op.cit. (note 12), at pp. 563-574.

79 In re W (A Minor), [1997] 3 WLR 768.

$G$ vs $F$, [1998] 3 FCR 1 Family Division.

Fitzpatrick vs Sterling Housing Association, [2001] 1A.C. 27.

[1998] Ch.304, at 319.

Stonewall press release, 25 June 1999.

Egan vs Canada, [1995] 2 SCR 513
} 
Security Act it was held that sexual orientation should be read into the prohibited grounds of discrimination under Article 15 of the Charter. In the case of $\operatorname{Re} K^{85}$ four lesbian couples applied for joint adoption of their children. The court held that there was no objective reason why homosexuals should be automatically prohibited from adopting. In May 1999 in the case of $M$ vs $H^{86}$ the Supreme Court rejected a heterosexual definition of 'spouse' under Ontario's Family Law Act. In this case a lesbian sought maintenance from her former partner, which she would have been entitled to had if they been a heterosexual couple. These decisions led the federal government to enact legislation to ensure recognition of same-sex relationships. ${ }^{87}$ However, recently considerable steps have been taken by the Canadian courts. In July 2003 the British Columbia Court of Appeal held that denying a marriage licence to same-sex couples was unconstitutional and a violation of their rights, and the Court approved the immediate registration of same-sex marriages in the province. ${ }^{88}$ The decision followed a similar ruling by the Ontario Court of Appeal. ${ }^{89}$ How and when these changes will be reflected throughout the rest of Canada seems destined to be the subject of intense debate in 2004.

In the USA, the Hawaii Supreme Court found in Baehr vs Lewin ${ }^{90}$ that there was prima facie sex discrimination contrary to its Constitution in marriage being confined to opposite sex partners. In 2000, the State of Vermont passed the Civil Unions Law, recognising same-sex relationships. Most remarkably, in November 2003 in the case of Goodridge vs Department of Public Health ${ }^{91}$ the Supreme Judicial Court of Massachusetts gave the legislature 180 days to amend discriminatory and unconstitutional state laws in order to extend marriage to same-sex couples. However, this has clearly been an enormous complex and controversial subject for the Americans. There are significant movements in the contrary direction, with President Bush publicly stating that he would, if necessary, support changing the US Constitution to ensure that states could not be required to recognise samesex relationships.

Although the climate in Latin America has not always been a happy one for gay people there have in fact been developments too in relation to the recognition of same-sex relationships. The Brazilian Congress has debated legislation that recognises same-sex couples rights along the lines of the French system. Although the proposal was initially unsuccessful after

$86 \quad M$ vs $H$, [1999] 2 S.C.R. Available at www.lexum.umontreal.ca/csc-scc/en/pub/1999/vol2/ html/1999scr2_0003.html (accessed 5 January 2004).

87 See Bonauto, M.L., 'The Freedom to Marry for Same-Sex Couples in the United States of America', in: Wintemute and Andenas, op.cit. (note 12), at pp. 177-207.

88 Barbeau vs British Columbia (Attorney General), [2003] BCCA 406.

89 Halpern vs Canada (Attorney General), [2003] O.J. No. 2268.

$90 \quad$ Baehr vs Lewin, 852 P 2d 44 (Haw 1993).

91 Goodridge vs Department of Public Health, No. SJC-08860.
} 
coming under attack from the Catholic Church, it has been under consideration for several years. ${ }^{92}$ News reports also suggest that Mexico City is drafting legislation that would allow for the recognition of same-sex relationships and also allow for the adoption of children by gay couples. ${ }^{93}$

\subsubsection{Africa and Asia}

There is very little evidence of the legalisation of same-sex relationships within Africa and Asia, and if one believes the words of President Mugabe of Zimbabwe then homosexuality is only a Western 'problem'. ${ }^{44}$ Comments such as these tempt one to caricature Africa and Asia States as somehow 'different' and less 'developed' than their Western counterparts when it comes to showing a liberal attitude to gay rights. Howard-Hassmann argues that we do not take these counter arguments from non-Western countries seriously enough:

'This new, Western ideal of the family permeates discussions of gay rights. Non-Westerners are asked to reshape one of their most sacred social institutions to accommodate what in many traditionalists' eyes are the shameful sexual desires of perverted individuals. As such, the demand for gay and lesbian rights is the latest in a series of what might be called cultural assaults against the non-Western world. Such an assault is highly objectionable to many outside the West, whether homosexuality is an "innate" characteristic or whether it is a social construction'. 95

But the reality is, of course, more complex, with evidence of homosexual behaviour throughout the world and growing evidence of a global gay consciousness emerging. There are for example, reports of (legally unrecognised) gay wedding ceremonies taking place in countries as diverse as India, ${ }^{96}$ Tanzania, ${ }^{97}$ Uganda, ${ }^{98}$ and Taiwan. ${ }^{99}$ In fact the unwillingness to admit that same-sex relationships exist in some countries has assisted gay people to celebrate their relationships. It is reported that lesbian wedding

92 Information from ILGA world legal survey, available at www.ilga.org.

93 www.datalounge.com/datalounge/news/record.html?record=12206 (accessed 15 December 2003)

94 Quoted in: Dunton and Palmberg, op.cit. (note 47), at p. 13.

95 Howard-Hassmann, loc.cit. (note 8), at p. 89.

Reported at www.news.bbc.co.uk/hi/English/world/south_asia/newsid_1357000/1357249.stm (accessed 16 November 2003). 
ceremonies have been performed in Kampuchea and Nepal, with officials unable to prevent the marriages, as the laws governing weddings were gender neutral. ${ }^{100}$ To ignore the reality of the gay relationships that do exist in these continents is to do injustice to their gay people. One Amnesty International report quotes an Indian gay rights activist, Ashok Row Kavi as saying, 'we are truly international and we are truly a planetary minority'. ${ }^{101}$ And in fact the question of recognising gay relationships has begun to be debated in some of these countries.

It is true that recent debates surrounding the issue of gay relationships in African countries have not always had positive results. For example, in a Namibian case, Frank, a German national, issued a challenge to the immigration laws that did not allow her to stay in Namibia on the basis of her lesbian relationship. Her claim was made partly on the basis of interference with her family life, guaranteed by Article 14 of the Namibian Constitution. In June 1999 the High Court held in her favour, but this decision was reversed by the Constitutional Court in March 2001 which did not consider the case a matter of 'family life'. ${ }^{102}$ A report by Amnesty International refers to anti-gay pronouncements being made in September 1999 by the President of Uganda in the 'wake of publicity' surrounding the 'wedding' mentioned above surrounding a gay marriage in Kampala.

However, at least we can see that signs are therefore beginning to emerge of a growing awareness of gay issues in these continents too and that the issue of gay relationships is a truly global one. Whilst it might be true to argue that gay people in Western democracies have a stronger identity, and have therefore been more vocal in their struggle for rights, and perhaps are nearer to having their relationships accepted and recognised, it is not enough to argue that gay people do not exist elsewhere or that gay-rights are a form of cultural imperialism. Whilst the homo/heterosexual polarisation might be a product of colonial legislation, the gay experience is clearly not uniquely Western. It may be true to say that Western countries are nearer a consensus, but that has been true in relation to a number of traditional rights. It is a human rights issue for all countries to engage with and a challenge that no international human rights tribunal should choose to ignore.

And indeed some of the signs are more positive. The South African Constitution is the first to contain a non-discrimination clause that specifically includes sexual orientation as a prohibited ground of discrimination. ${ }^{104}$ On the basis of this provision a Pretoria High Court found that a

\footnotetext{
100 Information from ILGA world legal survey, available at www.ilga.org.

101 Op.cit. (note 97 ), at p. 11.

102 Frank and Khaxas vs Chairperson of the Immigration Selection Board, Case SA8/99. Full text of judgment and dissenting opinion found at www.lac.org.na/pub/judgements/Frank1.PDF (accessed 2 January 2004).

103 Op.cit. (note 97), at p. 1

104 Constitution of the Republic of South Africa Act, No. 200 of 1993, s.8(2).
} 
lesbian in the South African Police Service had to right to register her partner as her dependent on her medical-aid scheme. ${ }^{105}$ In a March 2003 judgment concerning a lesbian couple and their children born by artificial insemination, the Constitutional Court declared a provision in the Children's Status Act 1987 unconstitutional as it did not create a legal relationship between children and the non-birth mother. ${ }^{106}$ The Association for Civil Rights in Israel has also reported that in June 2000 the Israeli Supreme Court allowed for the adoption by non-biological mother of her partner's son. ${ }^{107}$ In March 2001 the Chinese Psychiatric Association announced that it was dropping homosexuality from its list of psychiatric disorders. A British newspaper said of this event that the 'change in attitude reflects a more general shift in Chinese society - at least in urban culture towards a greater tolerance of different kinds of sexual behaviour' ${ }^{108}$

\section{CONCLUSION}

International human rights law has long recognised the human need for maintaining close relationships and the importance for these relationships to be offered legal respect and protection. But it has so far failed to recognise the value of gay relationships, and has left them outside of its support. At the same time there has been a failure to question whether this exclusion can be rationally justified. Whether or not same-sex relationships ought to be recognised is an issue that ought to be of concern to human rights lawyers. It is now becoming increasing apparent that gay relationships are a fact of life in all countries throughout the world. There is a suggestion that we are currently facing something of a 'gay-by boom', ${ }^{109}$ with many children being born in to same-sex relationships. As gay consciousness is raised and society becomes increasingly aware and tolerant of gay relationships, so the legal consequences of these relationships need to be addressed. It is not, therefore, in the interests of international and regional human rights tribunals to become irrelevant by ignoring relationships that are increasingly becoming a fact of life. Furthermore it is incumbent upon them that these relationships are addressed with respect for human rights.

It is submitted that no cogent reasons for this discrimination can be given, and that therefore gay relationships must be recognised as falling within the definition of 'the family' protected by international and regional human rights treaties. In asking for an expansive definition of 'the family', one simply seeks to reflect the reality of present day relationships

\footnotetext{
105 The Star \& SA Times International, 11 February 1998, at p. 6. www.acri.org.il/english-acr/engine/story.asp?id=73 (accessed 2 January 2004).

The Guardian, 7 March 2001, at p. 19.

Dunne, loc.cit. (note 66), at p. 2.
} 
throughout the globe, rather than to confine every relationship to a single pattern. It also asks for gay relationships to be recognised as valid and of equal worth, and for the importance to gay people of establishing loving and stable relationships to be respected. The international law of human rights has failed gay families because it has shut its eyes to their existence: it is time for these relationships to be acknowledged. 
